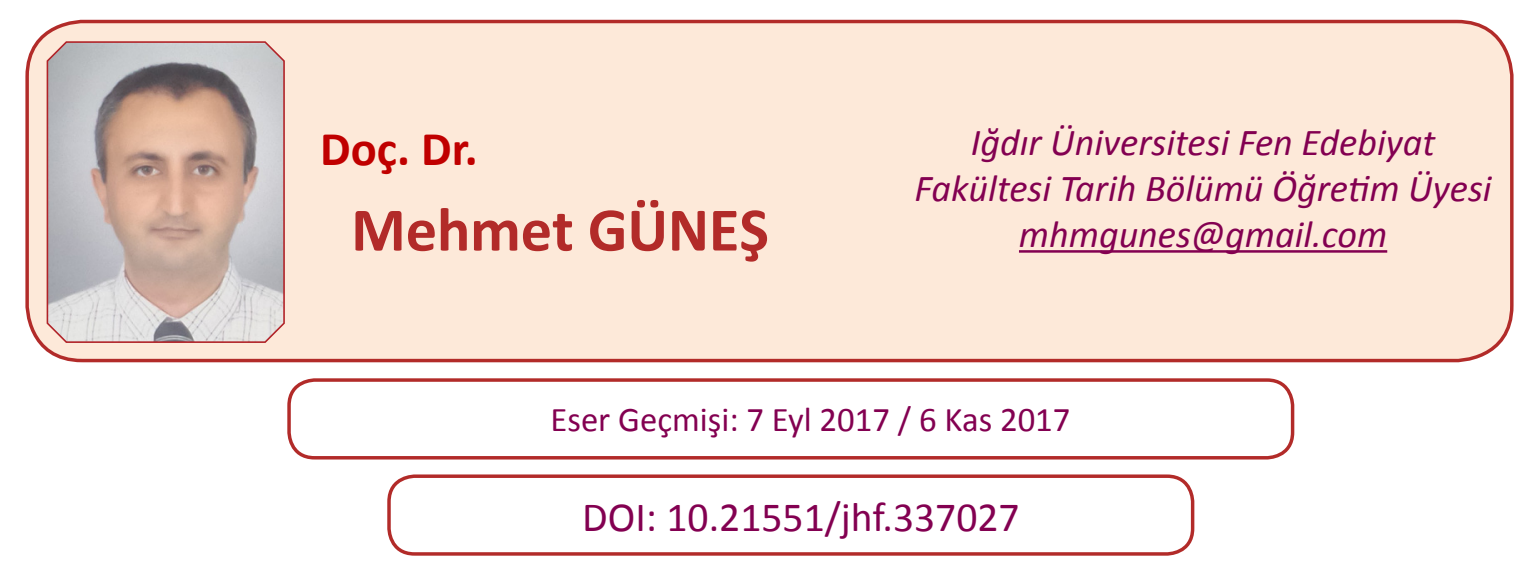

\title{
Osmanlı Devleti'nin Gayrimüslim Tebaaya Yaklaşımında Dönemsel Değişimler
}

\section{Periodical Changes About Approchment of The Ottoman State To Non- Muslim Subjects}

\section{ÖZET}

Osmanlı Devleti dinin, geleneklerin ve yönetici kesimdeki dünya algısının tezahürleri olarak tebaasının refahı ve çeşitli dini grupların barış içinde yaşaması için gerekli tedbirleri almıştır. Kuruluş devrinden itibaren benimsenen, Fatih döneminde kanun metinlerine yansıyan bu yaklaşım sonraki Osmanlı hükümdar ve yöneticileri tarafından devam ettirildi. Mülkî idareciler de gayrimüslimlerin dini, ekonomik ve sosyal hayatlarını korumaları için uyarıldı. Devlet, gayrimüslim din adamlarına imtiyaz beratları vermek suretiyle onlara bağlı kişilerin haklarını garanti altına aldı, ayrıca bu haklara saldırılmasını önledi. Tanzimat Fermanı ile belirtilen eşitlik prensibi gereğince, gayrimüslim unsurların hakları daha fazla gündeme geldi. Bu makalede, gayrimüslimlere verilen haklar, bu hakların hukukî temelleri ve devletin bunların icrasına yönelik tavrı hakkında bilgi ve analizler sunulmaktadır.

Anahtar Kelimeler: Osmanlı, Gayrimüslim, Zimmî, Millet, Eşitlik.

\section{ABSTRACT}

The Ottoman State took necessary measures for welfare of its subjects and different religious groups to live in peace as emergence of religion, tradition and world perceptions in the ruling class. This approchment which had been adopted from establisment period and reflected to law textes in time of The Conqueror had maintained by subsequent Ottoman rulers and dignitaries. Civil administrators also had been warned for protecting the religious, economic and social lives of non-muslims. The state by giving privilege orders to non-müslim clergymen in order to took under guarantee rights of the people dependent to them, and also prevented the attacks to these rights. In compliance with equality principle explained in Tanzimat Fermanı, the rights of non-muslims became a current issue more. In this article 
knowledge and analyses are presented about rights granted to non-muslims, essences of these rights and attitudes of the state towards the executing of these rights.

Keywords: Ottoman, Non-muslim, Zimmi, Religious group, Equity.

\section{Giriş}

Vatandaşlık ya da tebaa ve tabiiyet kavramları, bir devlete ait ve onun kendi sistemine bağlı bireyler olmayı ifade eder. Osmanlı özelinde ülkenin sınırları içinde yaşayan bireyler, ülke idaresine tabi olma vasfiyla ön plana çıkarılırken modern manada bireyler, aynı toprakları paylaşanlar olmaları hasebiyle değerlendirilir. Vatanı paylaşan kişiler olmaları açısından aslında Osmanlı gayrimüslimleri, bazı sınırlamaların dışında Müslümanlarda olduğu gibi İslam devletinin vatandaşı sayılırlar ve İslam hukukuna göre vatandaşlık ya da daha doğru bir ifadeyle zimmîlik hakkına sahip olurlar. Ayrıca gayrimüslimler için vatandaşlık sözleşmesi söz konusudur ve bu sözleșme, eman (himaye hakkı) kavramına dayanır. Bahis edilen metin, Müslümanlar açısından reddedilemez bir olgudur. Can, namus, çocuk ile malların korunması, dini hakları, Müslümana farz olan ibadetlerden muaf olmayı, cizye ile yükümlü tutulmayı ve asayişin temin edilmesi konularını kapsar. Bu noktada gayrimüslimler iç ve dış tehditlere karşı korunur, dini olmayan konularda hukuk önünde eşit muamele görür, kendilerine inanç özgürlüğü ve istediği dine geçme hakkı tanınır ve kendi ayinlerini serbestçe yapmalarına müsaade edilirdi. ${ }^{1}$

Osmanlı toplumu, genel itibariyle Müslüman ve gayrimüslim olmak üzere iki sınıftan meydana gelirdi. Nitekim bireylerin toplum içindeki statülerini belirleyen temel faktör dinî inançlardı. Dolayısıyla millet kavramı da Osmanlı'da modern manada bir ırka ya da aynı dile mensup topluluk için değil, aynı dine veya mezhebe bağlı halk için kullanılırdı. Bu düşüncenin dışa vurumu olmak üzere gayrimüslimlerin idaresiyle ilgili meselelerde kendi inançlarının ruhani reisleri yetkili kılınırdı. Yalnız gayrimüslimlerdeki bu din ve mezhep ayrımının sınırları bir Müslim ile gayrimüslim arasında gözetilen ayrım kadar keskin sınırlarla belirlenmiş değildi; öyle ki Müslümanlar ile gayrimüslimler birbirlerine mirasçı olamazken, farklı din ve mezhepten gayrimüslimler bunun aksine birbirlerine mirasçı olabilirlerdi. Müslümanlarla ayrı tutulmaları, dinin getirdiği farklılık sınırları dışına taşırılmazdı. Mesela gayrimüslimler, Müslümanlardan veya başka bir gayrimüslim inanç mensubu zümreden ayrı mahalle ve köylerde yașamaya zorlanamazlardı; ancak insanın doğası gereğince bu zümreler, daha iyi anlaşabilecekleri kişilerle aynı muhitleri paylaşmayı tercih ederlerdi. Gayrimüslimler, devletin idari kademelerinde yer alabilirlerdi. ${ }^{2}$

19. yüzyılda ve hassaten Islahat Fermanı'nın ilanından sonraki süreçte bu uygulamanın önü fazlasıyla açılmıştı. 19. yüzyıla kadar Rumların tercih edildiği ve hassaten tercümanlıkta istihdam edilme şeklinde sıkça görülen istihdam politikası, Rum isyanının akabinde

1 Ahmet Güneş, “İslam Hukukunda Gayrimüslimlerin Vatandaşlık Statüleri”, İslam Hukuku Araştırmaları Dergisi, Say1 11, 2008, s. 256-267.

2 Bilal Eryılmaz, Osmanlı Devleti’nde Millet Sistemi, Ağaç Yayınc1lık, İstanbul 1992, s. $32,33$. 
diğer gayrimüslimler lehine değişmişti. Ermenilerin memuriyete alımı açısından duruma bakıldığında, özellikle Rumların gözden düşmesiyle birlikte 19. yüzyılda Ermenilerin, kendilerine daha fazla alan açtıkları ve devletin üst kademelerine kadar yükseldikleri görülür. Hatta içlerinden son dönemlerde nazırlar da çıkmıştı. ${ }^{3}$ Devlet memurluğu dışında mimar, banker ve tüccar olan Ermeniler de vardı. ${ }^{4}$

\section{İslam Hukukunda Gayrimüslimlerin Yeri}

İslam hukuku, insanların can ve mal güvenliğine ve hayat hakkına saygılı olunması gerektiğini açıklamış, insan yaşamının önemini ve katletmenin vebalini bariz şekilde ortaya koymuştur. ${ }^{5}$ İslam devletinin yeni toprakları ele geçirmesi durumunda nasıl hareket edilmesi gerektiği de benzer şekilde fikhen belirlenmiştir. Buna göre Müslüman olmayan bir yer fethedilince oranın halkı ile bölgenin yeni sahipleri arasında zimmet akdi denilen bir anlaşma yapılırdı, bu minvalde İslam devletine tabi olmayı ve onun koyacağı kuralları kabul etmeyi taahhüt eden gayrimüslimlere zimmi denilirdi. Zimmî hukuku, İslam'ın temel iki kaynağı olan Kur'an ve peygamberin tatbikine dayanmaktadır. Kur'an'da belirtilen dinde zorlamanın olmaması düsturu ile peygamberin Medine'ye hicret ettikten sonra gayrimüslimler ile yaptığı Medine Vesikası, bu hukukun esaslarını belirleyen önemli kıstaslardır. Nitekim Medine'de peygamber, Yahudi gruplarla yaptığı anlaşma gereği onlara din, vicdan, mal ve can güvenliği teminatını vermiști. Medine'de yaşayan her kişi İslam devletinin tebaası oluyordu, dış saldırılara karşı devleti savunmakla yükümlü olan bu gruplar, devletin bünyesinde kendi hukuk sistemlerine bağlı kalıyorlardı. ${ }^{6}$

Peygamberin Medine'deki Yahudiler ile yapmış olduğu anlaşmayı, daha sonra başka bölgelerdeki ehli kitapla yaptığı antlaşmalar izlemişti. Bu minvalde Müslümanlarla anlaşma yapan azınlık gayrimüslimler için hadislerde muahid, Civarullahi ve resulihi, Biemanillahi ve emani Muhammed ve ehli zimmet kalıpları kullanıldı. ${ }^{7 *}$ Tevbe suresinde ve bazı hadislerde geçen zimmi kelimesi, tabiin döneminden itibaren yaygınlık kazandı. Emevi, Abbasi ve Selçuklu dönemlerinde zimmet ve zimmi tabirleri kullanıldı. Osmanlı Devleti'nde gayrimüslimler, İstanbul'un fethinden önce zimmi hükümlerine tabi oldular.8

Zimmet ve millet uygulamaları kapsamında gayrimüslimlere belli haklar ve garantiler sağlanırdı. İslam devleti, ilke olarak zimmilerin kendi din adamlarını seçme ve yetiştirme haklarını tanıdı, belirledikleri temsilciyi meşru gördü, hükümlerini geçerli saydı. Zimmilerin

3 Abdülhamit Kırmızı, II. Abdülhamid Dönemi (1876-1908) Osmanlı Bürokrasisinde Gayrimüslimler, Yüksek Lisans Tezi, Hacettepe Üniversitesi Sosyal Bilimler Enstitüsü, Ankara 1993, s. 124, 125.

4 Ahmet Gündüz, “XIX. Yüzyılda Osmanlı İmparatorluğu'nda Gayrimüslimlerin Hukuki Statüleri”, Türk Dünyası Araştırmaları, Sayı 175, 2008, s. 110, 113, 118.

5 Kur'an'da, haksız yere bir cana kıyan kişinin bütün insanları öldürmüş gibi olduğu ifade edilir (Maide 32: Kur'an-1 Kerim ve Açıklamalı Meali, Haz. Ảli Özek ve diğerleri, Türkiye Diyanet Vakfı Yayınları, Ankara 1997, s. 112).

6 Mehmet Akif Aydın, Türk Hukuk Tarihi, Beta, İstanbul 2014, s. 141-150. Zimmi, kendisine güvence verilen, koruma altına alınan kişi anlamına gelir (Mustafa Fayda, "Zimmî”, Diyanet İslam Ansiklopedisi, Cilt 44, 2013, s. 428).

7 * Zimmet kelimesi, bir kimsenin yüklendiği ve ödemek zorunda olduğu borç, alacak; sahip çıkma, antlaşma, ahit anlamlarına gelir (M. Fayda, “a.g.m”, s. 428).

8 Muhammed Çuçak, "İslami Literatürlerde Gayrimüslim Azınlık Kavramının Ortaya Çıkışı ve Tarihi Süreci”, Bingöl Üniversitesi İlahiyat Fakültesi Dergisi, Cilt IV, Say1 7, Y1l 2016/1, s. 130-133. 
Müslüman kadıya başvurabilme haklarını da saklı tuttu. Müslüman kadılar özellikle toprak anlaşmazlığı davalarına bakarlardı. Gayrimüslimler ile devlet veya gayrimüslimler ile Müslümanlar arasında çıkan anlaşmazlıklarda ise Müslüman kadılar yetkili kılınmıştı. Böyle durumlarda kadılar, Müslim-gayrimüslim ayırımı yapmaz ve tarafları eşit kabul ederdi.

Gayrimüslimler, konjonktürel ve dini istisnalar dışında mutlak bir iskân özgürlüğüne sahipti. İstedikleri bölgelerde yerleşir, mal alıp satabilirlerdi. Dolayısıyla İslam şehirlerinde gayrimüslimlere ait mahalleler kuruldu. Gayrimüslimler kendi mahallelerinde dindaşlarıyla birlikte yaşar, mahallelerini dini geleneklerine göre teşkil ederlerdi. Mahalle merkezinde kendi mabetleri olur, meskenler bu mabetler etrafında kurulurdu. Gayrimüslimler, mahallede İslam'da haram olmakla birlikte kendi dinlerine göre helal sayılan yiyecek içecekleri üretebilir ve satabilirlerdi. Resmi eğitimin dışında tutulan zimmilere ciddi bir eğitim desteği sağlanmamakla birlikte kadim sistemlerine olumsuz müdahale yapılmadı. Gayrimüslimler, devlet tarafından sağlanan sosyal hizmetlerden Müslümanlarla eşit bir şekilde yararlanırdı. Müslümanlardan toplanan zekatlar, Müslümanların yanında zimmi fakirlere de dağıtılırdı. Gayrimüslimlere tarımda kullanılmak üzere devlet hazinesinden bir veya iki yıl geri ödemesiz krediler kullandırılırdı. Zimmiler, istedikleri iş dalında çalışabilirlerdi. Askerlikten muaf oldukları için ticaret ve zanaatla uğraşır, zengin ve itibarlı sınıfı haline gelirlerdi. Tabiplik, eczacılık, kuyumculuk ve sarraflık gibi meslekler de büyük ölçüde zimmiler tarafından icra edilirdi. Kendilerine tanınan hakların dıșında gayrimüslimlerin sorumlulukları da vardı. Bunlar cizye, haraç ve öşür vergileri öderlerdi. Cizye, askerlikten muaf oldukları için gayrimüslim tebaadan alınan askerlikten muafiyet, koruma veya baş vergisi idi. Haraç vergisi, savaşla ele geçmiş olan arazilerden alınırdı. Oranları ve tahsil şekli bölgeye ve devlete göre farklılık arz edebilirdi. Öşür ise yılda bir defa alınan ticaret vergisiydi.

Bunların yanı sıra gayrimüslimler evlilik ve kılık kıyafet ve isimler hususunda Müslümanlardan ve birbirlerinden ayrı telakki edilirlerdi. Müslüman erkeğin, ehl-i kitap olan Yahudi ve Hıristiyan hanımlar ile evlenmesi caiz görülürken, Mecusilerle evlenmesi haram olarak kabul edilmiști. Gayrimüslim unsurun Müslümanların giydiği türden elbiseleri giymeleri ve aynı isimleri takmaları yasaktı. Müslümanın yükümlü olduğu dini görevler de Hıristiyan, Yahudi veya Mecusî için söz konusu değildi. Bu insanlar, Müslümanlarla aynı giyinirse ve aynı ismi taşırsa Müslüman sanılır, dini vecibeleri yerine getirmekten sorumlu tutulur ve bunları yerine getirmedikleri gerekçesiyle cezalandırılabilirdi. Dolayısıyla bu tatbik, zimmileri küçük düşürme, ikinci sınıf vatandaş olarak görmeye değil, koruma düşüncesine dayanırdı. ${ }^{9}$

\section{Osmanlı Döneminde Gayrimüslimlerin İdaresi}

Fatih, İstanbul'u fethettikten sonra Ortodoks Hristiyanları, Latin Hristiyanlardan koparmak ve Roma'nın Yunan kilisesi üzerinde etkisini önlemeyi düşündü ve bu minvalde devlet, zimmi uygulamasını yeniden düzenledi. Gayrimüslimleri kendi içinde hiyerarşisi olan cemaatler/milletler halinde Osmanlı sistemine entegre etti. Üç gayrimüslim inanç mensupları için ruhani liderler tayin etti. ${ }^{10} \mathrm{Bu}$ şekilde 1454 'te millet sistemi başlatıldı. Bu sistemde

9 Mehmet Mahfuz Söylemez, “İlk Dönem İslam Toplumunda Gayrimüslimlerin Yeri: Haklar ve Hoşgörü”, İstanbul Üniversitesi İlahiyat Fakültesi Dergisi, 2010, 22, s. 108-122.

10 Gülcan Avşin Güneş, “Osmanlı Devleti’nin Gayrimüslimlere Bakışı ve Klasik Dönem Millet Sistemi”, Sosyal ve Kültürel Araştırmalar Dergisi, Cilt I, Sayı 2, 2015, s. 16-18. 
insanlar, etnik ve dil farklara göre değil de din, mezhep ve inançlara göre sınıflandırıldı. Farklı ırktan olsalar da aynı inanca mensup insanlar bir millet olarak kabul edildi. Bu anlayış ekseninde Müslümanlar tek bir millet, gayrimüslimler de mezheplerine göre ayrı milletler oldu. Bunlar için Rum, Ermeni, Bulgar, Yahudi milleti gibi kavramlar kullanıld.. ${ }^{11}$

Millet sistemiyle birlikte millet kavramı hakkında tartışmalar çıkmıştır. Tolerans (Müsamaha) kavramı bu meyanda ele alındı. Ne var ki tek taraflı bağışlama, bir kusuru affetme veya görmezden gelme gibi anlamları içeren tolerans, Batı'da din savaşları için geçerli olsa da Doğu için söz konusu değildir; çünkü müsamaha birbirinin kusuruna bakmamayı ifade eder ve istenilen maksadı taşımaz. Osmanlı'daki millet sisteminin temelinde ise eman anlayışı vardır. Eman, İslam ülkesine girme veya teslim olma durumunda talep edilen güvenceyi ifade ederken, zamanla fethedilen bir yerin halkına uygulanan barış akdi anlamı yaygınlaştı. Kur'an'da civar kelimesiyle ifade edilen eman, hadislerde ahd ve zimmet kelimeleriyle de anlatılırdı. Bu sebeple Osmanlı tarihinde gayrimüslimlerin tabi olduğu kurallar için ahid veya zimmet terimleri kullanıldı. ${ }^{12}$

Millet sistemi, etnisiteye ve dil birliğine göre değil, din ve mezhep aidiyeti esasına dayandı. Dahası mesela Ermeniler, Ermeni milleti olarak değil de Gregoryen ve Katolik, 19. yüzyılda Protestan olarak üç millet halinde teşkilatlandı. Yahudi milleti de Karaim mezhebine mensup Yahudiler ile hem bir arada hem de ayrı ele alındılar. Ferman ve işlemlerde Musevi milleti hahambaşı ve Karaim millet başından söz edildi. Durumu daha farklı olan iki zümre ise Dürziler ve Yezidiler idi. İslam uleması ve Müslümanlar bu iki zümreyi kendilerinden görememişlerdi. Ancak iki grup millet olarak nitelenemezdi. Dürziler geç bir tarihte 1861'de yürürlüğe giren ve 1864'te yeniden düzenlenen Cebel-i Lübnan Nizamnâmesi ile Cebel-i Lübnan idaresine cemaat şeklinde temsil edilmek üzere katıldılar. Bir taraftan da Dürzîler kura-i şer'iye yoluyla askere alınıyorlardı.

Osmanlı millet sistemi, kendine has özelliği olan bir teşkilattı. Osmanlı cemiyetinin özgün sosyal ve kültürel ortamında gelişti. Millet sistemi, belli bir yerde yaşayanlar kadar, dağınık yerleșen ve bazen dil birliği göstermeyen Musevi grupları da kimlik açısından korudu. Başka bir şekilde ise dinler arasında geçişleri doğurdu. Bazı Bulgarlar ve Hıristiyan Arnavutlar ile Anadolu'nun Türk asıllı Türkçe konuşan Ortodoks Hıristiyanları Hellenleşti. Müslüman bazı unsurlar (Pomaklar), dilleri farklı olsa da Türk kimliğini benimsedi. Esasen İslam devleti gayrimüslimlerin ihtida dışında bir dinden öbürüne geçmesini hoş görmezdi; zaten Yahudi cemaatinden Hıristiyanlığa, Hıristiyanlardan Yahudiliğe geçiş gibi durumlar da pek yaşanmazdı. Ancak Hıristiyan cemaatin kendi içinde mezhep değiştirmesi olgusu ise meydana gelirdi. Ermeni Gregoryenler, Katolik ve Protestan olabilir, Süryani monofizistler de Katolik olabilirdi. Millet teşkilatında bir kimse, modern azınlık yapısının aksine aile, sülale ve cemaat içinde güvenle; geleneği ve sözlü kültürüyle yaşardı. Başka gruplarla ilişkisi ve çatışması ile rekabeti yoktu. ${ }^{13}$

11 M. Çuçak, "a.g.m”, s. 133, 134.

12 G. A. Güneş, “a.g.m.”, s. 14-21.

13 İlber Ortaylı, “Osmanlı İmparatorluğu'nda Millet Sistemi”, Türkler, Cilt 10, Yeni Türkiye Yayınları, Ankara 2002, s. 216-220. 
Osmanlı Devleti'nin hükümran olduğu sahada zimmiler ekseriyetle Rum, Ermeni ve Yahudi olmak üzere üç gruptan müteşekkildi. Bu topluluklar için zimmet şartlarını belirleyen İslam hukukunun yanı sıra hem Osmanlı'nın devlet ve millet geleneğinin doğurduğu uygulamalardan hem de ilgili gayrimüslim toplumun kendi yaşam biçimlerinden tevarüs eden bir örfî hukuk da uygulanır; bu realiteyi dikkate almak suretiyle yerine göre idarenin bașı ve mutlak sahibi olan sultan tarafından bazı imtiyaz veya yükümlülükleri belirlemek üzere fermanlar yayımlanırdı. İmtiyaz fermanları ya da beratları doğrultusunda her gayrimüslim sınıfın kendi din ve mezhepleriyle ilgili meseleleri yine kendi cemaatlerinin reislerine bırakılır; bu kapsamda olması itibariyle dini ayin ve ritüelleri düzenleme, din adamlarını seçme ve azletme, mabetlerin gelir ve giderlerini idare etme, çocukların eğitimi ve öğretimine dair işleri yürütme yetki ve salahiyetleri patrik, metropolit ve hahamlara havale edilirdi. Gayrimüslim ibadet yerlerinin imar ve tamiri kontrollü şekilde yapılır ve eski kiliseler ile havraların, şekilleri değiştirilmemek şartıyla tamirine izin verilirdi. Karar mekanizmasının işletilmesi ve hakkın sahibine teslimi bakımından Osmanlı Devleti'nde kanunların tatbik edilişi esnasında Müslümanlar ile gayrimüslimler arasında ayrımcılık yapılmazdı. Haklı olanın müstahakkı verilir, kimliğine ve inancına bakılmazdı; bu çıkarımı doğrulamak üzere bakılan mahkeme kayıtları gerekli verileri sunmaktadır. Zira kadı sicilleri, birçok davada gayrimüslimlerin haklı bulunduklarını göstermektedir.

Osmanlı'nın kuruluş esasları yönünden İslam’a dayandı̆̆ı için başından beri riayet ettiği, tüm reayanın korunması ve her zümreye adil davranılması ilkesi, 19. yüzyıl Avrupa'sının önce kendi içinde başlatıp akabinde Osmanlı'ya dayattı̆̆ı nasyonalizmin bir tezahürü olarak şekil değiştirme yoluna girdi. Özde yine tebaanın korunması anlayışına dayanan bu yaklaşımda zimmî hukukun dışına çıkılması ihtimali kendini gösteriyordu. Dolayısıyla dinin belirlediği zimmi statüyü sürdürmek ile muasır Avrupa devletlerinin dindaşları olan Hıristiyan halk için dayattığı ve bunu yeri geldiğinde siyasi emelleri için araç haline de getirdiği eşitlik, özgürlük ve kişi haklarını verme ikilemi arasında sıkıșan Osmanlı idaresi, söylem değiştirmeye ve salt insan olmaktan gelen bir inanç serbestliği vurgusunu yapmaya başladı. Bu konuyla ilgili bir örnek olmak üzere burada derc edilebilecek bir ifade kapsamında II. Mahmud, "ben tebaanın Müslümanlarını camide, Hristiyanlarını kilisede, Musevisini de havrada fark ederim, aralarında bașka gûne bir fark yoktur, cümlesi hakkındaki muhabbet ve adaletim kavidir ve hepsi hakiki evladımdır" demiştir. Daha seküler bir maskeye bürünen bu cümle, nüvesi bakımından İslam'ın zimmet hukukunun döneme uyarlanmasıydı.

Eskiden beri uygulana geldiği biçimde gayrimüslimler, bazı detayları havi kısıtlamalar dışında kilisede ve havralarda toplu olarak ya da evlerinde bireysel olarak ibadet edebilirlerdi. Bu türden bir inanç ve ibadet serbestliğini tanımak üzere gayrimüslim ruhani reislere devlet tarafından berat verilir ve reayanın kendilerine mahsus ibadetlerini rahatça yapmaları yönünde teminatta bulunulurdu. Bununla da iktifa etmeyen devlet, gayrimüslimlerin rahat bir şekilde ibadet edebilmeleri için gerekli güvenlik tedbirlerini alırdı. Tabiidir ki dönemin idare anlayışının ve dini hassasiyetlerin bir neticesi olarak yönetim erkinin sahibi hanedanın ve kurucu güç olan Türk halkının dini olan İslam'ın fıkıh kuralları çerçevesinde ve özellikle de ibadetler noktasında gayrimüslimlere bazı kısıtlamalar getirilirdi. Mesela Hıristiyanların dini bir ritüeli olan; ancak çevreye ses vermesi ve Müslüman halkı ajite etme riski taşıan çan çalmaya dair bazı özel durumlarda kısmi yasaklar getirilebiliyordu. Bunun başka bir sebebi de çan çalmanın, Müslüman ahali tarafından İslam'a karşı bir saldırı şeklinde telakki edilmesiydi. Gerekçeleri ve tehlikeleri düşünülerek ve neticede doğurabileceği sosyal infial de 
hesaba katılarak icra edilen çan çalma kısıtlamasında, her şeye rağmen gayrimüslim reayanın da haklarını gözetmek ve onları da teskin etmek gayesiyle mümkün olduğunca serbestlik getirilmeye çalışılır; namaz vakitleri haricinde ve Müslümanların duymayacakları bir tonda çan çalınmasına izin verilirdi. Kimi gayrimüslim zümreler, çan çalma tatbikinin farklı bir versiyonu olan tahta çalma ritüelini icra ederlerdi. Yalnız bu faaliyetin meydana getirdiği ses, yakındaki Müslüman ahalinin şikâyetine sebep olduğu zaman, hassasiyetine binaen yerine göre tahta çalma işi yasaklanmakla birlikte şikâyeti mucip olmayacak kadar mümkün olduğunca bu faaliyete de izin verilmeye çalışılırdı.

Dinî bir vecibenin ifası olmak üzere gayrimüslimlerin kendileri açısından kutsal olan mekânları ziyaret amacıyla Kudüs şehrine hac için gitmelerine de herhangi bir yasak ve sinır getirilmezdi. Diledikleri takdirde onlar da hac görevi için hareket edebilirlerdi. Bunların yanı sıra zimmiler, cenaze töreni ve defni esnasında yapacakları işlemleri yürütme konusunda da serbest bırakılmışlardı. Nitekim her gayrimüslim sınıf, kendi inancına göre cenaze töreni yapıp mevtayı yine kendi mezarlı̆̆ına defnedebilirdi. Gayrimüslimlere ait mezarlıklar da insana ve tebaaya olan değerin bir göstergesi ve İslam'ın devlete sorumluluk olarak yüklediği bir hukukun gereği olarak devlet tarafından korunurdu. Osmanlı tebaasının din ve mezhebine bakılmaksızın eğitim ve öğretim hakkı mevcuttu; yalnız dönemin kavrayış ve yaşayış biçiminin neticesi olarak tedrisatta tevhit söz konusu değildi. Dolayısıyla da her sınıf ahali (bu sınıflama inanç temeline göre belirlenirdi), kendi inanç ve geleneklerine uygun olarak çocuklarını yetiştirme hakkına sahipti. Böyle olunca da her Müslim ve gayrimüslim inanç mensubu kendi eğitim ve öğretim işlerini yine kendi itikatlarına ait mekteplerinde ve mabetlerinde yürütürlerdi. ${ }^{14}$

Osmanlı Devleti'nde farklı halk sınıfları din esasına göre belirlenir, resmi tasnifte etnik kimlik kast edilmezdi. Dolayısıyla da tebaanın tüm sınıflarına hoşgörüde bulunmak veya tüm halk zümrelerinin hukukunu gözetmek kabilinden deyimler, etnik değil, dini ve mezhebi olguları kapsardı. Hukuki açıdan Osmanlı hoşgörüsünün önemli bir ayağını adalet anlayışı oluştururdu. Sosyal farklılıklar, kanunlarla güvence altına alınmıștı. Bu nedenle de hukuk sisteminde her cemaat ve inanç mensubu, kendisine tahsis edilmiş hareket alanı içerisinde serbest yargllanma talebinde bulunabilirdi. Modern hukukun aksine Osmanlı hukukunda benzer davaların her kesim için aynı tür mahkemede görülmesi şeklinde bir uygulama şartı yoktu. Bu prensibin yerine Müslüman ve gayrimüslimler için farklı adalet sistemleri tatbik edilirdi.

İslam hukukunu ve Türk Müslüman ananelerini temel alan şer'i mahkemelerin yanı sıra diledikleri takdirde gayrimüslimler için kendi din ve mezheplerine mensup ruhani reisleri tarafından idare edilen cemaat mahkemeleri ile yabancı uyruklu kişilerin hukuki işlemlerine bakan konsolosluk mahkemeleri vardı ve haliyle yargıda tek aynı konulara bakmak için bile bölünmüş, parçalı bir muhakeme yapısı mevcuttu. Bu mahkemelerde alınan kararlar, siyasi erkin tanıdığı salahiyet çerçevesinde uygulanırdı. Hükümet organları karşısında kendini ifade etme konusunda gayrimüslimlere mümkün mertebe her kolaylık sağlanırdı. İnanç ve ibadetlerini yaşama konusunda engellerden korunan gayrimüslim cemaatlerin üyeleri, hoşgörü ve hürriyetin tüm tebaaya teşmil edilmesi ve halkın herhangi bir şekilde memurların

14 Ali İhsan Karataş, “Osmanlı Devleti'nde Gayrimüslimlere Tanınan Din ve Vicdan Hürriyeti”, Uludağ Üniversitesi Ilahiyat Fakültesi Dergisi, 15/1, 2006, s. 268-283. 
menfi yaklaşımlarına muhatap olmamaları nazarından gayrimüslim ahali, Osmanlı yönetici sınıfıyla doğrudan değil, kendi mensup oldukları cemaatlerin idarecileri vasıtasıyla irtibat içerisine girerlerdi. ${ }^{15}$

Kilise ve manastır gibi ibadet yerlerinin tadili konusunda hükümet, ahaliye kolaylık sağlar, imar ve tamir işlerine müsaade ederdi. Yalnız belirli şartlara riayet edilmesi hususunu teyit ve tekit ederdi. Bunların tamiri ile inşasında genellikle kadim olma ve aslına fazla bir şey eklemeden tamir etme prensipleri geçerli olurdu. Bu kısıtlamaların getirilmesi, idaresinde İslam'ı referans alan bir devletin İslam dıșı tebaasının haklarını, dini alanı ihmal etmeden ve dinin insana verdiği değeri dikkate alarak icra etmesi anlamına gelirdi. ${ }^{16}$

Osmanlı idaresinde gayrimüslimler, kendi patrikleri tarafından merkezde temsil edilirdi. İdareyi ilgilendiren önemli bir mesele, vergi tahsili ve cemaatin iç nizamını sürdürmekti. Bu işleri yürütmede patriklik önemli rol oynardı. Tüm kilise ve manastırlar için ruhban tayini ve azli, patriğin arzı ve sarayın onayıyla gerçekleşir; cemaat mensuplarının vergileri de patrik vasıtasıyla tahsil edilirdi. Ermeniler örneğinde görüleceği üzere genel olarak patrikler, ilgili cemaatin ruhani ve sivil üyelerinden oluşan bir konsey tarafından seçilir, ardından sarayın onayıyla birlikte patriğe yetki ve sorumluluklarını bildiren berat verilirdi. İstanbul Ermeni patriği, Osmanlı Devleti ile resmi işlerini, Divan-ı Hümayun'a sunduğu arzuhaller vasıtasıyla yürütürdü. Arzuhal sunma hakkı sadece patriklere ait değildi. Ruhban ve cemaat mensupları da şahsi veya sosyal konularda İstanbul patriğinin aracılı̆̆ı olmadan Divan-ı Hümâyûn'a müracaat edebilirlerdi. Gregoryen ve Katolik Ermeniler arasındaki çekişmeler, devlet nazarında iç mesele olarak görülür, meselenin dini yönüne girilmezdi. İşler reayanın haklarına tecavüz ve düzenin bozulması noktasına gelirse patrik veya cemaat mensuplarının müracaatı üzerine konuya müdahale edilirdi. Bu aşamada da yine Ermeni cemaatinin temsilcisi olan Gregoryen Ermeni patriği muhatap alınır ve düzenin devamına gayret edilirdi. ${ }^{17}$

Gayrimüslim unsurlar ile İttihat ve Terakki Cemiyeti arasındaki ilişkiler ise Abdülhamid yönetimine karşı bir ittifak olarak ortaya çıkmıştı. Muhalefet, faklı kesimlerin güç birliği içerisinde sürdürüldü. İttihat ve Terakki Cemiyeti hem muhalefeti genişletmek hem de dağılmakta olan unsurları bir arada tutmak için gayrimüslimlerle iş birliğine gitti. Özellikle Hıristiyan Ermeni ve Rumlarla iş birliği, yönetime karşı mücadelelerinde Avrupa devletlerinin de desteğini sağlardı. Gayrimüslimler açısından bakılınca; Abdülhamid'in iktidarında Ermeni ve Rumların özerklik ya da bağımsızlık amaçlı faaliyetleri için uygun ortam meydana gelemezdi. Dolayısıyla oluşturulan geniş kapsamlı bir koalisyon sonucunda Meşrutiyet ilan edildi ve bir süre sonra Abdülhamid tahttan indirildi. Ancak tarafları bir arada tutan neden de ortadan kalkmış oluyordu. Sonunda Yahudi cemaati ile İttihat ve Terakki arasındaki birliktelik temelde devam ettiyse de Rum ve Ermeni cemaatleriyle yollar ayrılmaya başladı. Hıristiyan unsurlar hem büyük devletlerden cesaret aldıkları hem de sığınabilecekleri Yunanistan ve Bulgaristan gibi bağımsız devletleri olduğu için İttihat ve Terakki'yi Abdülhamid yönetimini aşmak için bir araç olarak kullandı. Önce imtiyaz, daha sonra bağımsızlık taleplerine uzanan

15 Bilal Eryılmaz, “Osmanlı Devleti’nde Farklılıklara ve Hoşgörüye Kavramsal Bir Yaklaşım”, Osmanlı, Cilt 4, 1999, s. 238-240.

16 M. Macit Kenanoğlu, Osmanlı Millet Sistemi / Mit ve Gerçek, Klasik, İstanbul 2004, s. 289.

17 Ensar Köse, “İstanbul Ermeni Patrikliği’nin Osmanlı Hükümeti’yle Münasebetlerine Tesir Eden Dinamikler (18. Yüzyılın İlk Yarısı)”, Osmanlı Medeniyeti Araştırmaları Dergisi, 2017, Volume 3, No. 5, s. 5-15. 
süreçte her iki unsur da cemiyet ile ilişkilerini kesip hasım oldular.

Ermenilerden ve Rumlardan farklı bir politika izleyen Museviler, cemiyetle birliktelik içindeydi. Bu durum tabana da yayıldı. 31 Mart hadisesinde Çanakkale, Keşan, Edirne ve Selanik'ten toplanan 700 Musevi gönüllü, Hareket Ordusu'na katıldı. Museviler ile Hıristiyan unsurların, İttihat ve Terakki Cemiyeti'yle olan ilişkileri farklı saiklerden kaynaklandı. Museviler, yaşadıkları farklı tarihi sürecin de etkisiyle İttihat ve Terakki Cemiyeti'nin egemen olduğu 1908-1918 yılları arası ile izleyen dönemde devletin yanında yer aldılar, Türk unsurun geleceği ile kendi geleceklerini bağlantılı gördü ve bu çizgiyi kararlılıkla sürdürdüler. ${ }^{18}$

\section{Gayrimüslimlerin Devlet Hizmetinde İstihdam Edilmesi}

Osmanlı klasik dönem bürokrasisinde kökeni gayrimüslim ailelere dayanan önemli sayıda idareci vardı. Bunlar etnik açıdan Türk, Arnavut, Boşnak, Gürcü, Abhaz, Rum, Çerkez, Hırvat, Ermeni, İtalyan ve Arap olabilirdi. 19. yüzyıldan önce İslam'a girmeden yönetici sınıfına girebilen Ortodoks Rumlar, patrik makamının bulunduğu Fener bölgesinde aristokrat bir zümre olarak devlet idaresinde rol almışlardı.

16. yüzyılda Divan-ı Hümâyûn tercümanlığı görevini genellikle İtalyan, Macar, Alman, Leh asıllı mühtediler yerine getirirken 17. yüzyıldan itibaren bu göreve Osmanlı tebaası Rumlar getirildi. Bu kişiler, devletin sırlarına vakıf oldukları için 1821 isyanından sonra tercümanlık görevinden çıkarıldılar. Aynı işleri yürütmesi için Babıâli Tercüme Odası açıldı. Burası, zamanla Müslüman memur ve bürokrat yetiştiren merkez haline geldi. Rumlar 1821 isyanında gözden düşmekle birlikte 1836'da Hariciye Nezareti kurulunca yine Osmanlı diplomasisinde görev almaya başladılar. 1830'lardan sonra Mavroyeni, Musurus, Kalimaki, Aristarki, Fotiadi, Karateodori, Aleko, Karaca gibi paşa ve beyler, önemli dış işleri görevlerini yürüttüler.

Yunan bağımsızlığının başka ayrılıkçı hareketlere örnek olmasını önlemek için Osmanlı devlet adamları, reform ve batılılaşma hareketi başlattı. Bu yolda Avrupa'dan yeni uygulamalar, Osmanlı'ya uyarlanmaya çalışıldı; eşitlik düşüncesine evrilme yaşandı. Eşitlik fikri, resmi politikaya dönüştü ve Osmanlıcılık teorisi halini aldı. Osmanlıcılık fikrinden hareketle din ayrımı yapmayan bir sadakat tesis edilmek istendi. Bu şekilde seküler bir bürokratik elitoluşma süreci başlatıldı. Osmanlı Devleti, Tanzimat Fermanı ile eşitlik anlayışını devlet politikası olarak ilan etti. Merkez ve taşra teşkilatında ve dış işlere dair görevlerde Ortodoks Rumlar, Katolikler, Gregoryen Ermeniler ve Yahudiler görev yaptı. 1840’lardan itibaren vilayetlerde ve kazalarda teşekkül eden meclislerde ve merkezdeki diğer kurullarda gayrimüslim üyeler ve cemaat temsilcileri görev aldı.

Osmanlı hükümeti, Kırım Savaşı koşullarında Tanzimat sistemini geliştirme gereği gördü. 1856'da ilan edilen Islahat Fermanı'nda, tüm tebaanın hangi milletten olursa olsun devletin hizmetine kabul edilecekleri, ehliyet ve kabiliyetlerine göre nizamlar gereği memuriyetlerde istihdam olunacakları belirtildi. Gayrimüslimlerin bürokrasideki yeri bundan artış gösterdi. Bu fermanda vaat edilenler doğrultusunda birkaç ay içerisinde gayrimüslim

18 Halil Şimşek, “İttihat ve Terakki Yönetimi ve Gayrimüslim Cemaatler”, Çanakkale Araştırmaları Türk Yıllığı, Y1l 12, Bahar 2014, Say1 16, s. 183-189. 
tebaadan temsilciler, yürütme yetkileri ön planda olan Meclis-i Vâlâ'ya atandı. Taşradaki idare meclislerinde muteber ve ruhban temsilciler yer aldı, merkezi idarede eğitimli gayrimüslimler görev aldı. Gayrimüslimler yeni kurulan belediye idarelerine, kaza ve vilayet meclislerine tayin edildiler. Rumlar bu süreçte özellikle 1860'larda görev dağılımında zirveye ulaştılar. Ermeniler ise yaklaşık on yıl kadar sonra zirveye ulaştılar. Ermeniler, bu üstünlüklerini 19. yüzyılın son çeyreğinde başlattıkları milliyetçi hareketlerine kadar sürdürdüler. Bundan sonra da bürokrasiye girmekte geç kalan Yahudiler gözde oldular.

Abdülhamid döneminde mahalli memur istihdamında azalma oldu; merkezden tayin uygulaması en küçük memur atamasına kadar ulaştı. Bu devirde düzenli olarak tutulan Sicill-i Ahval defterlerine göre bürokrasi kozmopolit idi. Sarayda gayrimüslim hekim bulunduran padişah, Hazine-i Hassa'yı Ermeni nazırlara emanet etti, merkezdeki idari ve istişari kurullara İstanbul'un nüfuzlu gayrimüslimlerini atadı, Hariciye Nezareti'ne gayrimüslim nazırlar tayin etti. Gümrük idarelerini Avrupa'dan getirtilen yabancı müsteşarlara teslim etti. Taşra idaresinde gayrimüslim valiler getirildi. Cebel-i Lübnan, Girit, Sisam ve Şarki Rumeli'de gayrimüslim idareciler hüküm sürdü. Bu idarî pratikte, tüm tebaayı birleștirmeyi öngören Osmanlılık düşüncesi etkili olmuştu. ${ }^{19}$

Abdülhamid'in iktidarında Yahudi memur istihdamında da artış oldu. Bu dönemde Dâhiliye sicil defterlerinde yaklaşık 92 bin memurun kaydı vardır. Bu memurların 303'ü Yahudi kökenli idi. Abdülhamid'den önce devlet hizmetinde yalnız 28 Yahudi görev yapmıştı. Dolayısıyla Yahudi memur sayısı, Abdülhamid'in saltanata gelmesi ile birlikte giderek artış gösterdi. 1885 yılında İstanbul yasayan Yahudilerin \%0,44'ü bir kamu hizmetinde çalışırken, Ermenilerde \%0,58'i ve Rumların \%0,38'i kamuda görev yapıyordu. Yahudiler sayıca olmasa da oran olarak Rumları geçti. Bu dönemde Yahudilerin devlet hizmetine alınmasındaki büyük artışın nedenleri, Osmanlı Yahudilerinin 19. yüzyılın ikinci yarısından itibaren modernleşme sürecine girmeleri; Rum ve Ermeniler arasında milliyetçi hareketlerin artmasından dolayı bu milletlere güven duygusunun azalması idi. Yahudiler, İttihad ve Terakki döneminde daha parlak bir süreci yaşadılar. Gayrimüslimlerin ayrılıkçı hareketlerine karşı İttihad ve Terakki, Yahudilere daha olumlu yaklaştı. Parti ile bazı Yahudilerin organik bağı da vardı. Bu yakınlık, Yahudilerin devlet hizmetinde istihdamını olumlu yönde etkiledi. Mecliste ve nezaretlerde çeşitli görevler üstlendiler. ${ }^{20}$

\section{Osmanlı'daki Din ve Vicdan Hürriyetine Dair Örnekler}

Osmanlı ülkesinde gayrimüslim ahalinin dini hayatını serbestçe yaşamasına müsaade edilirken, bir zümrenin dini yaşamına yönelik başka bir inanç mensupları tarafından müdahale edilmesinin önüne geçilmeye çalışılır, bunun için taşradaki sorumlu ve yetkili mercilere gerekli emirler, tedbir amacıyla gönderilirdi. Özellikle de Hıristiyanların ayin vakitlerini bildirmek üzere kiliselerde icra ettikleri tahta çalma ritüeline kimsenin müdahale etmemesi için mülkî idarecilere, yeri geldiğinde mülki idarenin merkezdeki en üst makamı olan Sadaretten uyarı ve emir yazıları gönderilirdi. Bu ifadeleri somut şekilde gösterecek olan bir örneğe göre Osmanlı ülkesindeki Ermeni patriği ve millet meclisi, Van dahilinde ayin yapmak

19 A. Kirmız1, a.g.t., s. 5-11, 124-126.

20 Musa Kılıç, "Sicill-i Ahvâl Kayıtlarına Göre II. Abdülhamid Dönemi Osmanlı Bürokrasisinde Yahudi Memurlar”, OTAM, 31/Bahar 2012, s. 132-134, 151, 152. 
için reayayı kiliseye çağırmak amacıyla tahta çalmalarının eskiden beri adet olduğunu, ancak bazı kişilerin kendilerine müdahale ettiklerini belirterek bu menfi vaziyetin men edilmesini istemiş; bunun üzerine söz konusu edilen müdahaleleri önlemeleri için Van kaymakamı ile naibine Sadaretten emir gönderilmişti. Olayın vahametini fark eden bölgedeki kaymakam da Müslüman ve reaya hanelerinin bir arada bulundukları yerlerde tahta çalmalarını; ancak bunu yaparken Müslüman ahaliyi de taciz ve rahatsız etmemeleri gerektiğini metropolitlere bildirerek farklı inanç mensuplarının ortak faydalarını gözetmiş ve taraflar arasında herhangi bir sürtüşme yaşanmasına mahal vermemişti. ${ }^{21}$

Osmanlı yönetim anlayışına göre Müslüman ve gayrimüslim ahalinin işlemleri inanç temelinde kendilerine has ayrı idareciler tarafından yürütülürdü. ${ }^{22} \mathrm{Bu}$ kişilerden herhangi birinin diğerlerinin ișlerine karıșmamaları da gerekirdi. Sistemin uygulamasında aksamalar meydana geldiği takdirde ise duruma gerekli müdahaleler yapılarak sorunlar giderilmeye çalışılırdı. Bu konuya dair bir örnekte görüldügü kadarıyla, Ermeni patriği ile millet meclisi üyeleri merkeze bir yazı göndererek Erzurum’a bağlı Bayburt kazasının köylerindeki bazı muhtar ve meclis üyelerinin Ermenilerin mezhep işlerine karıșıp istemedikleri papazları suçlayarak hapsettiklerini, bu müdahalenin menini ve papazların gerektiğinde marhasalara teslim edilerek hapsedilmelerini istemişlerdi. Bu șikâyet üzerine merkezden Erzurum valisine yazı gönderilmiş, her sınıfın din ve dünya işlerinin icrasında kolaylık olması gerektiği; memurların böyle uygunsuz işler yapmasının yanlış ve patriklik beratına aykırı olduğu belirtilmiș, ardından söz konusu kişilerin araştırılıp men edilmesi; papazların hapsedilmesi gerekince kendi marhasalarına teslim edilerek hapsedilmeleri emredilmişti. ${ }^{23}$

Osmanlı ülkesinde bulunan Katolik, Ortodoks, Protestan ve Yahudi milletlerinin her biri, mahalle ve köylerde kendi din ve mezheplerine mensup temsilciler tarafından idare edilirlerdi. Hristiyanlar ve Yahudiler için bu yerleşim birimlerine kocabaşılar tayin edilirdi. ${ }^{24}$ Dahası aynı köy ve mahallede yaşayan farklı milletlerin de kendi inançlarına bağlı ayrı idareciler tarafından yönetilmeleri gerekirdi. Çünkü tüm ahalinin işleri yalnızca bir mezhebin idarecileri tarafından yürütüldüğü takdirde farklı mezheplere mensup halk mağdur edilebilirdi. Böyle uygunsuz olayların yaşandığına dair şikâyet ve talepler mevcuttur.

Bu hususla ilgili olarak Tekfurdağı sancağında bulunan bir Protestan vekil, Protestanların ișlerine bakan Ermeni idarecilerin görevlerini kötüye kullandıklarını ve Protestanlardan yüksek vergi aldıklarını belirterek iki milletin vergi, cizye ve nüfus işlerinin ayrılmasını ve kendilerinin de bir kocabaşı seçmelerine izin verilmesini talep etmişti. Konu merkezde değerlendirildikten sonra isteğe uygun gerekli düzenlemenin yapılması için Tekfurdağı kaymakamına yazı gönderildi. Ayrıca mezhep değiştiren ahalinin yeni mezheplerine ait başka idareciler seçme hakları vardı. Bu konuya dair bir örnekte, Musul eyaletindeki Protestan vekili İstanbul'a gönderdiği yazısında, Yakubî milletine mensup olan sekiz ailenin Protestanlığa geçtiği ve akabinde eski kocabaşıların görevlerini kötüye kullanarak bu ailelerden vergi ve cizyeleri tahammüllerinden fazla olarak tahsil ettiğini, bu nedenle söz konusu ailelerin perişan olduğunu, dolayısıyla işlerinin eski milletlerinden ayrılıp yeni mezheplerine mensup kendi

21 BOA, A.MKT, 206/7, 15 Haziran 1849/23 Receb 1265.

22 BOA, C.DH, 185/9201, 15 Şubat 1836/27 Şevval 1251.

23 BOA, HR.SYS, 2821/36, 5 Ocak 1854/5 Rebiülâhir 1270.

24 BOA, HAT, 687/33363-C, 2 Eylül 1834/27 Rebiülâhir 1250. 
seçtikleri bir kocabaşı tarafından yürütülmesini istemişti. Durum ele alındı ve bu ailelerin kendileri için ayrı bir kocabaşı tayin etmelerine karar verildi. ${ }^{25}$

Başka bir örnekte de açıklandığı üzere Tekfurdağı'ndaki Katolik başpiskoposu da Tekfurdağı ve civarındaki Katolik ve Ermeni nüfusun vergilerinin karışık olarak toplandığını ve bunun bazı uygunsuz durumlara yol açtığını belirterek vergilerin mezhepler arasında ayrı olarak toplanmasını istemiști. Bu talep üzerine merkezden Tekfurdağı kaymakamına gönderilen yazıda, her milletin vergisinin kendi idarecileri tarafından tahsil edilmesi gerektiği için Katoliklerin vergilerinin de Ermenilerden ayrılarak kendi idarecileri vasıtasıyla toplanması emredildi. ${ }^{26}$

Gayrimüslimler, Osmanlı taşra idaresinde faaliyet gösteren idare meclislerinde görev alarak gayrimüslim ahaliyi temsil ederlerdi. Örneğin kaza idare meclisinde reis dışında genel olarak Müslüman ve gayrimüslim azalar bulunurdu. ${ }^{27}$ Bunun dișında Müslüman müftülerin yanı sıra gayrimüslim ruhani reisler kaza meclislerinde yer alırlardı. ${ }^{28}$ Ayrıca bu azalar, Müslüman ve gayrimüslim temsilcilerin bir araya gelmesiyle oluşmayabilirdi. Nitekim bazı kaza meclislerinde görevli tüm azalar Müslüman iken bazı kazalarda ise gayrimüslim olabilirdi. ${ }^{29}$

\section{Sonuç}

Osmanlı idaresi, yayıldı̆̆ı geniş coğrafyada gayrimüslimler için bir hukukî statü belirlemiş ve bu insanların din, vicdan, mal ve namus hürriyetlerini korumaya özen göstermiş; ruhani reisler vasıtasıyla onlara hak ve yükümlülükler vermiş ve uygulamaların da takipçisi olmuştu. Bu politikasını öncelikle İslam hukukuna dayandırmış ve kendisinden önceki İslam devletlerinin tecrübelerini miras olarak almıștı. Gayrimüslimleri zimmî hukuku dahilinde idare etmiş ve onlara hem haklar hem de sorumluluklar getirmişti.

İstanbul'un fethiyle birlikte devletin daha da büyüyüp kurumlarının yerleşmesinin ardından İslami pratikten ödün vermeden kendine has bir idari düzenlemeyi ifade eden millet sistemini geliştirmiş, bu kapsamda gayrimüslim din adamlarını da kendi din ve mezhep mensuplarından sorumlu kılarak işleri merkeze fazla yük oluşturmadan kendi içinde halletme yoluna gitti. Bu usul de 19. Yüzyıla kadar bu şekilde uygulana gelen sistem, özellikle dünyadaki

25 Her iki olay da aynı belgede geçer (BOA, HR.MKT, 41/39, 6-30 Aralık 1851/12 Safer-6 Rebiülevvel 1268).

26 BOA, HR.SYS, 2821/48, 30 Kasım 1858/23 Rebiülâhir 1275.

27 Osmanlı dönemindeki birçok vilayet salnamesinde bu durumu gösteren örnekleri bulmak mümkündür. Konuyla ilgili bilgiler, salnamelerin kazalar için hususi olarak ayrılan başlıkları altında mevcuttur. Uygulamanın yaygınlığını göstermek amacıyla birçok salname incelendi ve durum tespiti yapıldı. Bu konuda bilgi edinilebilecek baz1 vilayet salnameleri: Konya 1285, 1286, 1287, 1293. Trabzon 1286, 1287. Bosna 1286, 1293. Erzurum 1287, 1291. Selanik 1287, 1293. Haleb 1285, 1286, 1287, 1290. Kastamonu 1286, 1287, 1291. Edirne 1287, 1290, 1292. Diyarbakır 1287, 1292. Sivas 1287. Suriye 1286, 1291. Tuna 1291. Hüdavendigar 1293. Adana 1293.

28 Salnamelerin azalara ayrılan bölümlerine bakılabilir: Hüdavendigar 1286, 1287. Bosna 1285, 1287. Adana 1287.

$29 \mathrm{Bu}$ konuyla ilgili detaylar, vilayet salnamelerinin kazalara ayrılan başlıkları altında bulunur, bilgi için bakınız: Haleb 1285, 1286, 1287. Kastamonu 1286, 1287. Adana 1287. Konya 1285, 1286, 1287. Cezayir-i Bahr-i Sefid 1287. Hüdavendigar 1287. Tuna 1285, 1286, 1287. Buradaki salnameler ile arşiv evrak1, “Osmanlı'nın Din ve Vicdan Hürriyeti Bağlamında Ermenilere Tanıdığı Haklar, Kadim Dostluğun Yüzyıllık Açmazında Türk-Ermeni İlişkileri Uluslararası Sempozyumu Toplumsal Bellek, Önyargılar ve Gerçekler, 08-11 Nisan 2015, Antalya” ile "Osmanlı Devleti'nde Kaymakamlık (1842-1871)" ve "Osmanlı Döneminde Muhtarlık ve İhtiyar Meclisleri (1829-1871), Kitabevi, İstanbul 2014” künyeli çalışmalarda mevcuttur. 
yeni sosyal eğilimlerin Osmanlı'ya tesiriyle 1830'lardan itibaren aksamaya başlayınca yeni çareler arandı ve eşitlik ilkesi dairesinde tüm tebaanın Osmanlılık bilinciyle vatan çatısında birleşip devlete bağlılıklarını temin etme tatbiki devreye konuldu. Gayrimüslimler, ülke yönetimine de iştirak ettirilmek suretiyle vatana sahip çıkmaları sağlanmaya çalışıldı. Ne var ki tüm çabalar akim kalacaktı.

\section{Kaynaklar}

\section{BOA (Başbakanlık Osmanlı Arşivi).}

A.MKT (Sadaret Mektubi Kalemi Evrakı), 206/7, 15 Haziran 1849/23 Receb 1265.

C.DH (Cevdet Dahiliye), 185/9201, 15 Şubat 1836/27 Şevval 1251.

HAT (Hatt-ı Hümayun), 687/33363-C, 2 Eylül 1834/27 Rebiülâhir 1250.

HR.MKT (Hariciye Nezareti Mektubi Kalemi Evrakı), 41/39, 6-30 Aralık 1851/12 Safer-6 Rebiülevvel 1268).

HR.SYS (Hariciye Nezareti Siyasi), 2821/36, 5 Ocak 1854/5 Rebiülâhir 1270.

HR.SYS (Hariciye Nezareti Siyasi), 2821/48, 30 Kasım 1858/23 Rebiülâhir 1275.

\section{Salnameler}

Adana Vilayet Salnamesi 1287, 1293.

Bosna Vilayet Salnamesi 1285, 1286, 1287, 1293.

Cezayir-i Bahr-i Sefid Vilayet Salnamesi 1287.

Diyarbakır Vilayet Salnamesi 1287, 1292.

Edirne Vilayet Salnamesi 1287, 1290, 1292.

Erzurum Vilayet Salnamesi 1287, 1291.

Haleb Vilayet Salnamesi 1285, 1286, 1287, 1290.

Hüdavendigar Vilayet Salnamesi 1286, 1287, 1293.

Kastamonu Vilayet Salnamesi 1286, 1287, 1291.

Konya Vilayet Salnamesi 1285, 1286, 1287, 1293. 
Selanik Vilayet Salnamesi 1287, 1293.

Sivas 1287.

Suriye Vilayet Salnamesi 1286, 1291.

Trabzon Vilayet Salnamesi 1286, 1287.

Tuna Vilayet Salnamesi 1285, 1286, 1287, 1291.

\section{Araştırma ve İnceleme Eserler}

Aydın, Mehmet Akif, Türk Hukuk Tarihi, Beta, İstanbul 2014.

Çuçak, Muhammed, "İslami Literatürlerde Gayrimüslim Azınlık Kavramının Ortaya Çıkıșı ve Tarihi Süreci”, Bingöl Üniversitesi İlahiyat Fakültesi Dergisi, Cilt IV, Sayı 7, Yıl 2016/1, s. 119-139.

Eryılmaz, Bilal, “Osmanlı Devleti’nde Farklılıklara ve Hoşgörüye Kavramsal Bir Yaklaşım”, Osmanl, Cilt 4, Yeni Türkiye Yayınları, Ankara 1999, s. 236-241.

Eryılmaz, Bilal, Osmanlı Devleti’nde Millet Sistemi, Ağaç Yayıncılık, İstanbul 1992.

Fayda, Mustafa, “Zimmî”, Türkiye Diyanet Vakfı İslam Ansiklopedisi, Cilt 44, 2013, s. 428434.

Gündüz, Ahmet, "XIX. Yüzyılda Osmanlı İmparatorluğu’nda Gayrimüslimlerin Hukuki Statüleri", Türk Dünyası Araştırmaları, Sayı 175, 2008, s. 109-136.

Güneş, Ahmet, "İslam Hukukunda Gayrimüslimlerin Vatandaşlık Statüleri", İslam Hukuku Araştırmaları Dergisi, Sayı 11, 2008, s. 255-268.

Güneş, Gülcan Avşin, “Osmanlı Devleti’nin Gayrimüslimlere Bakışı ve Klasik Dönem Millet Sistemi”, Sosyal ve Kültürel Araştırmalar Dergisi, Cilt I, Sayı 2, 2015, s. 1-30.

Güneş, Mehmet, Osmanlı Devleti’nde Kaymakamlık(1842-1871), Kitabevi, İstanbul 2014.

Güneş, Mehmet, Osmanlı Döneminde Muhtarlık ve İhtiyar Meclisleri (1829-1871), Kitabevi, İstanbul 2014.

Karataş, Ali İhsan, “Osmanlı Devleti'nde Gayrimüslimlere Tanınan Din ve Vicdan Hürriyeti”, Uludağ Üniversitesi İlahiyat Fakültesi Dergisi, Cilt 15, Sayı 1, 2006, s. 267-284.

Kenanoğlu, M. Macit, Osmanlı Millet Sistemi/Mit ve Gerçek, Klasik, İstanbul 2004.

Kılıç, Musa, "Sicill-i Ahvâl Kayıtlarına Göre II. Abdülhamid Dönemi Osmanlı Bürokrasisinde Yahudi Memurlar”, OTAM, 31/Bahar 2012, s. 129-156. 
Kırmızı, Abdülhamit, II. Abdülhamid Dönemi (1876-1908) Osmanlı Bürokrasisinde Gayrimüslimler, Yüksek Lisans Tezi, Hacettepe Üniversitesi Sosyal Bilimler Enstitüsü, Ankara 1993.

Köse, Ensar, “İstanbul Ermeni Patrikliği'nin Osmanlı Hükümeti'yle Münasebetlerine Tesir Eden Dinamikler (18. Yüzyılın İlk Yarısı)”, Osmanlı Medeniyeti Araştırmaları Dergisi, 2017, Vol. 3, No. 5, s. 1-24.

Kur'an-ı Kerim ve Açıklamalı Meali, Hza. Ali Özek ve dilerleri, Türkiye Diyanet Vakfı Yayınları, Ankara 1997.

Ortaylı, İlber, “Osmanlı İmparatorluğu'nda Millet Sistemi”. Türkler, 10, Yeni Türkiye Yayınları, Ankara 2002, s. 216-220.

Söylemez, Mehmet Mahfuz, "İlk Dönem İslam Toplumunda Gayrimüslimlerin Yeri: Haklar ve Hoşgörü”, İstanbul Üniversitesi İlahiyat Fakültesi Dergisi, 2010, 22, s. 99-124.

Şimşek, Halil, "İttihat ve Terakki Yönetimi ve Gayrimüslim Cemaatler”, Çanakkale Araştırmaları Türk Yıllığı, Yıl 12, Bahar 2014, Sayı 16, s. 181-192. 